\title{
Water reuse: A review of recent international contributions and an agenda for future research*
}

\author{
David Saurí \\ Universitat Autònoma de Barcelona. Departament de Geografia \\ david.sauri@uab.cat
}

\section{Ana Arahuetes}

Universitat d'Alacant. Institut Interuniversitari de Geografia

ana.arahuetes@gmail.com

Received: March 2018

Accepted: July 2018

Published: May 2019

\begin{abstract}
Wastewater treatment and the generation of recycled water for eventual reuse are raising important expectations worldwide as a resource of interest to solve future water needs. In this review, we first acknowledge the important technical advances made in relation to wastewater treatment although we also point out some of the current challenges faced by wastewater treatment technology, most especially new families of pollutants linked to pharmaceuticals and home consumer products. Most of the review highlights the main points of research on the perception of recycled water and the determinants of its public acceptance in the social and psychological literature with an emphasis on the so-called 'yuck factor'. The review also identifies several areas for future research relating recycled water with social territorial and environmental issues.
\end{abstract}

Keywords: recycled water; social perception and acceptance; yuck factor; territorial and environmental dimensions

* The authors acknowledge the useful criticisms and suggestions made by our colleagues in the research project "Uso de recursos hídricos no convencionales y adaptación a las sequías en el litoral mediterráneo: realidades y propuestas para una planificación resiliente del agua" funded by the Spanish CICYT under contract number CSO2015-65182-C2-1-P. Likewise, we would like to thank the editors and two anonymous reviewers for their helpful comments and suggestions on a previous version of the manuscript. 
Resum. La reutilització de l'aigua: una revisió de les contribucions internacionals recents $i$ una agenda per a futures recerques

El tractament de les aigües residuals i la generació d'aigua reciclada per reutilitzar-la posteriorment han creat expectatives importants arreu del món com un recurs d'interès per resoldre futures necessitats d'aigua. En aquest article es reconeixen els avenços tècnics recents en relació amb el tractament d'aigüies residuals, tot i que també s'assenyalen alguns dels reptes actuals a què s'enfronta la tecnologia de tractament d'aigües residuals, sobretot les noves famílies de contaminants vinculats a productes farmacèutics i a productes de consum domèstic. La major part de la revisió es dirigeix a destacar els principals resultats de la recerca sobre la percepció de l'aigua reciclada i els determinants de la seva acceptació pública en la literatura sociològica i psicològica fent èmfasi en l'anomenat "factor fastic»" (yuck factor). La revisió també identifica diverses àrees per a futures investigacions relacionant l'aigua reciclada amb aspectes socials territorials i mediambientals.

Paraules clau: aigua reciclada; percepció i acceptació social; factor fastic; dimensions territorials i ambientals

Resumen. La reutilización del agua: una revisión de las contribuciones internacionales recientes y una agenda para futuras investigaciones

El tratamiento de aguas residuales y la generación de agua reciclada para su posible reutilización están creando muchas expectativas en todo el mundo como un recurso de interés para resolver futuras necesidades de agua. En este artículo se reconocen los importantes avances técnicos realizados en el tratamiento de aguas residuales, aunque también se señalan algunos de los desafíos actuales, especialmente las nuevas familias de contaminantes vinculados a productos farmacéuticos y productos de consumo doméstico. La mayor parte de la revisión se dirige a resaltar los principales resultados de la investigación sobre la percepción del agua reciclada y los determinantes de su aceptación pública en la literatura social y psicológica poniendo énfasis en el llamado "factor asco» (yuck factor). La revisión también identifica varias áreas para futuras investigaciones relacionando el agua reciclada con cuestiones sociales, territoriales y ambientales.

Palabras clave: agua reciclada; percepción y aceptación social; factor asco; dimensiones territoriales y ambientales

Résumé. La réutilisation de l'eau: une évaluation des contributions internationales récentes et un programme de recherche future

Le traitement des eaux usées et la production d'eau recyclée pour une éventuelle réutilisation suscitent des attentes importantes dans le monde entier en tant que ressource d'intérêt pour résoudre les futurs besoins en eau. Dans cette analyse documentaire, nous reconnaissons tout d'abord les progrès techniques en matière de traitement des eaux usées, tout en soulignant certains des défis actuels rencontrés par les technologies de traitement des eaux usées, notamment les nouvelles familles de polluants liés aux produits pharmaceutiques et domestiques. La majeure partie de l'analyse documentaire explore la littérature sociale et psychologique sur la perception de l'eau recyclée et les déterminants de son acceptation publique en mettant l'accent sur le soi-disant " facteur beurk » (yuck factor). L'article identifie également plusieurs domaines de recherche future concernant les relations entre l'eau recyclée et des questions sociales territoriales et environnementales.

Mots-clés: eau recyclée; perception et acceptation publique; facteur beurk; dimensions territoriales et environnementales 


\section{Summary}

1. Introduction 4. Conclusion: Towards a research

2. Water reuse: the technical approach agenda on water reuse based on social, and new concerns

3. Contributions with a predominantly territorial and environmental factors

Bibliographical references social and psychological orientation

\section{Introduction}

The United Nations World Water Development Report of 2017 was dedicated to wastewater defined in the title as the 'Untapped Resource' (WWAP, 2017). The main argument of the report was that, rather than a problem in need of treatment and proper disposal, wastewater is a reliable source that could be part of the solution to the world's water problems as long as it is properly treated to become useful again for humans and the environment. The report insists on the critical importance of wastewater when populations, urban growth and climate change, among other stressors, are pushing current freshwater reserves to their limits in many areas of the planet. According to the report, 80 percent of wastewater worldwide is released untreated to the environment, causing severe pollution and health problems. Rich countries, on the other hand, treat about 70 percent of their wastewater to improve the quality of aquatic environments and add a strategic resource to water supply options in certain water scarce areas.

Water reuse has both advantages and disadvantages (Figure 1). The interest in water reuse appears to transcend political and social boundaries. In January 2018, Angel Simon, President and CEO of the AGBAR Group (the private company holding the water supply and sanitation concession of the Barcelona area) publicly defended the urgent need to reuse water to contend with the next, inevitable drought that will affect the city (La Vanguardia, 23 January 2018). He considered reclaimed water cheaper than desalination and (implicitly) disregarded the conventional solutions of dams and inter-basin aqueducts as a means to solve water problems. From a very different ideological perspective, the Fundación Nueva Cultura del Agua (FNCA; New Water Culture Foundation), in its recent proposal for a sustainable water policy for Spain, also expressed the need to incorporate reclaimed water to the supply portfolio as a means to alleviate the pressures on aquatic ecosystems (FNCA, 2018). On the other hand, water reuse is gaining prominence among many water professionals as a resource deserving to occupy a relevant place in future water supply matrixes (Stijn et al., 2015). In sum and contrary to other alternatives (dams, inter-basin transfers, desalination), wastewater appears to have the favourable view of a wide spectrum of relevant stakeholders in the water arena. 
Figure 1. Advantages and disadvantages of water reuse

- Advantages
- Elow regularity
- Environmental benefits
- Gecological flows)
higher quality water for priority
uses
Quality water on demand

Source: Own elaboration.

Our main objective in this review is to provide a basic summary of recent contributions to the analysis of wastewater and wastewater reuse especially in what concerns social and psychological matters although a brief reference is also made to technical issues. The focus on the former is also intended to further develop some social and territorial dimensions that we believe have been little addressed in the literature. Our methodological approach is mainly bibliographical and we have attempted to include references on the social, spatial and environmental dimensions of wastewater in a variety of geographical settings. Our main source of information for references on these and other topics related to wastewater has been the SCOPUS@ database.

As most references included in this report show, the professional and scientific communities share to a large extent this supportive attitude towards reclaimed water although they are also aware of the problems that water reuse may create and that explain, with a few exceptions, the currently minimal presence of this resource in the water supply mix. Although the volumes treated have increased, this has not translated into a parallel increase in reuse. Factors such as the lack of regularity in effluent quality, the use of effluents to satisfy ecological flows, the difficulty of converting potential demands into actual demands or the lack of planning make their expansion difficult (Melgarejo and López, 2016). Currently, about 1 billion $\mathrm{m}^{3}$ of treated urban wastewater is reused annually in the European Union, mainly for irrigation. This figure barely represents 2.4 percent of the treated urban wastewater and less than 0.5 percent of annual EU water withdrawals. Cyprus and Malta reuse more than 90 percent and 60 percent of their wastewater respectively, while Greece, Italy and Spain reuse between 5 and 12 percent of their effluents, mostly for irrigation (EU, 2017). Although these are indeed laudable figures, the reality of water reuse in Europe does not correspond to the expectations mentioned above. A poll by the European Commission in 2014 on water reuse pinpointed several causes of this lack of success. First and foremost, one major problem was the absence of common environmental and health regulations in the EU regarding water reuse. Second, there were some concerns in relation to the free 
circulation of foodstuffs irrigated with treated wastewater. Third, tariff and managerial structures for treated wastewater are inadequate or non-existent. Fourth, despite the potential benefits of water reuse, stakeholders appeared to be little interested while public acceptance remains problematic. Finally, technical obstacles and scientific uncertainties are still relevant, especially in what concerns new generations of pollutants. Most of the references included in this report aim to answer these and other constraints to the full development of water reuse.

As first step, it is necessary to clarify the terminology used in the literature. Table 1 summarizes the main concepts related to water reuse including the very important distinctions between direct and indirect applications for both potable and non-potable water. Especially relevant in the literature is the distinction between direct and indirect potable reuse. The first option is rarely found. Some exceptions can be found in Windhoek (Namibia) or, to a certain extent, in Singapore (Mujeriego, 2015; Soon et al., 2008). Military and space missions, as well as the Concordia Station of the Antarctic, also directly

Table 1. Terminology used to describe water reuse

\begin{tabular}{|c|c|}
\hline Term & Definition \\
\hline Water recycling & $\begin{array}{l}\text { Recovery of wastewater from a specific use and redirection of } \\
\text { the water back to the original use; typically involves only one } \\
\text { use or user. Applied predominantly to industrial applications, } \\
\text { such as in the steam-electric, manufacturing and minerals } \\
\text { industries. }\end{array}$ \\
\hline Wastewater reclamation & Treatment or processing of wastewater to make it reusable. \\
\hline Reclaimed water & $\begin{array}{l}\text { The end product of wastewater reclamation that meets water } \\
\text { quality requirements for biodegradable materials, suspended } \\
\text { matter and pathogens. }\end{array}$ \\
\hline Recycled water & $\begin{array}{l}\text { Reclaimed water that meets appropriate water quality require- } \\
\text { ments and is reused for a specific purpose. }\end{array}$ \\
\hline Direct reuse & $\begin{array}{l}\text { The direct use of reclaimed water. Applications include agricul- } \\
\text { tural and landscape irrigation, cooling water and other industrial } \\
\text { uses, urban applications and dual water systems. }\end{array}$ \\
\hline Indirect reuse & $\begin{array}{l}\text { Mixing, dilution and dispersion of treated wastewater by dis- } \\
\text { charge into an impoundment, receiving water or groundwater } \\
\text { aquifer prior to reuse, such as in groundwater recharge }\end{array}$ \\
\hline Direct potable reuse & $\begin{array}{l}\text { Incorporation of reclaimed water into a potable water supply } \\
\text { system, without relinquishing control over the resource }\end{array}$ \\
\hline Indirect potable reuse & $\begin{array}{l}\text { Incorporation of reclaimed water into a potable water supply by } \\
\text { including an intermediate step in which reclaimed water is mixed } \\
\text { with surface or groundwater sources upstream of intakes for } \\
\text { drinking water treatment facilities. }\end{array}$ \\
\hline Non-potable water reuse & $\begin{array}{l}\text { Includes all water reuse applications other than direct or indirect } \\
\text { use for drinking water supplies }\end{array}$ \\
\hline
\end{tabular}

Source: Levine and Asano (2004). 
reuse water. The second option is much more common although unknown by many people in large river basins who may be drinking surface water that has already been drunk, discharged and treated upstream at the intake points of water purification plants serving their areas of residence.

The wide range of potential uses makes reclaimed water a basic resource for both short-term needs and longer-term applications. The critical point appears to be whether non-potable uses can be extended to other uses involving a closer contact with the human body and whether and under what circumstances reclaimed water can end up in the taps of residential consumers without causing a major social outcry. This objective requires extensive research on several fronts, especially regarding the invariably complex relationships between controversial technologies and social responses. Hence, the main objective of this article is to review a number of (mostly scientific) references on water reuse and its different dimensions. This review will be organized according to three main points. The main distinction will be made between contributions that are more technical in nature (first part) and contributions with a predominantly social and political focus (second part). In the third and final section of the review, an attempt will be made to identify research topics that may be important and that somehow have not yet received the attention they deserve.

\section{Water reuse: the technical approach and new concerns}

Wastewater requires advanced treatment that adapts physical, chemical and biological parameters to future uses. Depending on the characteristics of the effluent and the required quality, a combination of treatments is used (pretreatment, primary treatment, secondary treatment and advanced treatment). A more specific scheme and therefore more expensive is shown in Figure 2. This scheme consists of a physical-chemical treatment, followed by a filtration system (sand, membranes) and, finally, by a disinfection process (UV, chlorination). A problem encountered by users of reclaimed water, mainly in agricultural irrigation, and which often limits use, is the high conductivity of effluents after treatment. This problem appears mainly in coastal areas and has led to the incorporation in some cases of desalination (reverse osmosis), which may increase costs substantially. Extensive technologies (lagooning, infiltration-percolation or artificial wetlands) can also be used. These involve lower costs but treatment capacities may require large areas, which translates into lower efficiencies (Arahuetes, 2017).

Wastewater treatment plants (WWTPs) that employ advanced treatments can currently remove pollutants to the point of producing effluents of a prepotable quality in accordance with the parameters required by different water quality regulations. In recent years, however, new pollutants (usually referred to as 'micropollutants' or 'emerging contaminants') discovered in tiny concentrations thanks to the rapid development of sophisticated analytical methods, are raising concerns due especially to the uncertainty associated with their effects (Perez et al., 2010). The reason behind the increasing presence of 
Figure 2. Chart of wastewater treatments

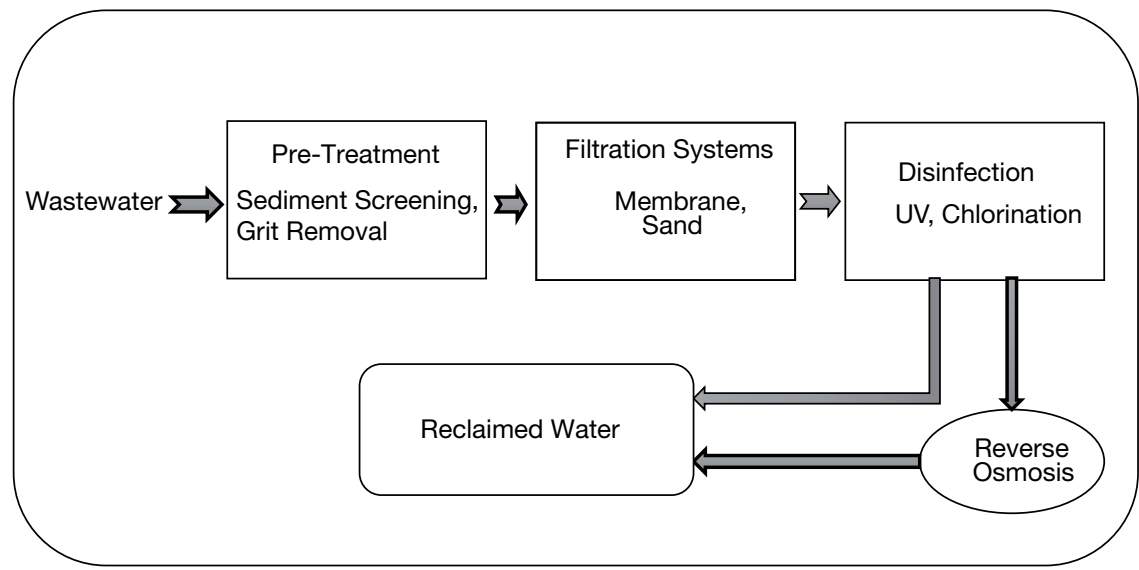

Source: Own elaboration.

these pollutants is the growing consumption by individuals and households of products containing these compounds, the difficulties of the human body to metabolize them, and inadequate means of disposal (Yang et al., 2017). Some of these substances, including pharmaceuticals, pesticides and personal care products used in households, are difficult to remove in WWTPs and may require more sophisticated treatments (Jonas et al., 2015) since their impact on river ecosystems may be significant in terms of endocrine disruption and sex disorders, among other problems (Montes-Grajales et al., 2017). Some of the extra treatments that may be needed to remove these substances are membrane filtration, granular activated carbon and advanced oxidation processes (Yang et al., 2017). One side effect of this new family of pollutants could be the increase in the cost of treatment and therefore the likely increase in the price of and taxes on domestic water.

The emergence of new pollutants highlights the need to develop international guidelines to regulate water reuse. Currently there is a proliferation of national or sub-national rules and standards for determining health risks which are still highly dependent on local contexts and particular approaches. While the development of international regulations may have important benefits (well-defined targets and risk calculation methods), flexibility should also form part of the regulations to allow for economic, social and cultural differences regarding health management (Anderson et al., 2001). Europe, in particular, lacks a regulatory regime for water reuse despite the fact that some member states (Greece, Spain) have developed comprehensive legislations in this regard. Such a regulatory regime is seen as critical for the technological and managerial expansion of the sector (Fawell et al., 2016).

Recent contributions on the technical approach increasingly point to the importance of understanding water reuse in terms of risk assessment and risk 
management, especially regarding how technology confronts possible impacts on human health. This is best reflected in the so-called water safety plans (WSPs). According to Almeida et al. (2014), WSPs aim to provide systematic risk assessment of urban water cycles and include, among others, a characterization of water systems; the identification, analysis and evaluation of risks; and the selection of risk reduction actions. This approach has been applied to water reuse schemes, which highlight the importance of chemical hazards assessment and also identify possible remediation measures (Dominguez-Chicas and Scrimshaw, 2010). Therefore and in as much as they are predominantly riskbased frameworks, WSPs could in principle better organize the evaluation of water reuse projects (Kot et al. 2015). Other authors, however, are sceptical about risk analysis and risk management due to the problems involved in handling uncertainty and values and therefore propose including uncertainty and trade-offs among actors as an explicit component of these analyses (Hall and Borgomeo, 2013). For example, in cases where reclaimed water may be the only available alternative for irrigation, the trade-off is between accepting a certain level of risk and not irrigating at all.

\section{Contributions with a predominantly social and psychological orientation}

Social sciences have shown a long and sustained interest in water reuse as one of the multiple environmental crossroads between nature, technology and society. Most of the research focuses on understanding the contexts and drivers of human attitudes and behaviour regarding water reuse (Wester et al., 2016). It is relatively easy to understand the social concern for these flows. After all, poor water quality was behind many of the epidemic episodes that ravaged urban areas of Europe and North America in the 19th century and is still a major cause of death in many areas of the developing world, especially among children. Therefore, a strong aversion to polluted water is hardly surprising even when technology may radically change the quality matrix. The study of public attitudes and behaviour regarding water reuse has been approached from different angles, which we will attempt to summarize in what follows.

First, a number of general reviews (see, for instance, Duong and Spahores, 2015) identify the main causes behind public reluctance to embrace water reuse as a source of water for residential functions. Perhaps the most important obstacle is the so-called 'yuck' factor which is related to health concerns and remains a major cause of successful opposition to water reuse schemes. The yuck factor, powerfully conveyed to the public through the appealing slogan of 'from toilet to tap, but crap is still crap', expresses a reaction of disgust and rejection. The slogan has been able to defeat proposals for reuse schemes in Australia and California, among other places (Hurlimann and Dolnicar, 2010; van Vuuren, 2009; Hartley 2006; Po et al., 2003). However, there are also many examples of successful water reuse schemes indicating that the yuck factor is strongly dependent upon historical, cultural, technological, social, and 
other contextual factors that may modify psychological propensities to reject what may be perceived as impure (Harris-Lovett et al., 2015). Likewise, and as we will see below, issues of public involvement and trust also appear to play an important role in the acceptance or non-acceptance of water reuse schemes (Russell and Hampton, 2006).

Beginning with psychological approaches, disgust and sensitivity to pollution stand as two major causes in the rejection of water reuse no matter how sophisticated and comprehensive treatment systems may be. Although many times undergoing sophisticated purification processes, treated wastewater will always carry the stigma of 'contagion' (Rozin et al., 2015) and thus be systematically abhorred. According to psychological research, certain socio-demographic groups are more prone to reject water reuse. Gender (female), education (low levels) and sensitivity to pathogens have been found to be related to discomfort and disgust for treated wastewater (Wester et al., 2015). This segment of the population, on the other hand, has been identified with strong risk aversion attitudes which may have an economic and social component. Thus, less educated and poorer females may encounter social and environmental risks more frequently compared to the average population.

Several socio-psychological theories have been used to explain people's attitudes and behaviour regarding water reuse. In terms of planned behaviour, Dolnicar and Hurlimann (2009) found that, as expected, people are ambivalent towards water reuse. The authors argued that more information is needed but also trust in scientific opinions. At the same time, however, people also trust their immediate social circles (family, friends) in rejecting these water flows. The cultural theory of risk has also been used to explain individual attitudes and behaviour. As predicted by this theory, pre-existing attitudes to uncertainty and specific worldviews shape risk perception and acceptance of water reuse schemes (Price et al., 2012). One study found a particular adherence by participants to the 'risk society' thesis (Marks et al., 2008). Finally, another set of theories is based on the assumption that water reuse schemes are not simply technical artefacts isolated from social, ecological or institutional networks (Bell and Aitken, 2008). Therefore, acceptance of water reuse entails, above all, a parallel acceptance of these networks, their organization and their relationships that is more likely to succeed if networks are seen as 'democratic' in the sense used by Latour (2005).

Other than certain psychological propensities more or less included in the theories introduced above, many authors suggest that the acceptance of water reuse schemes bears a strong relationship with trust (Hurliman, 2007). Not only trust in the authorities responsible for regulating water use, but also in the plethora of stakeholders intervening in the process, from academics to professionals and politicians. An important caveat to be made is that trust is also socially and politically mediated. Therefore, acceptance may depend on trust but trust implies reciprocity, where the latter is understood as incorporating public values and aspirations into water policy (Marks, 2006; Ormerod and Scott, 2012). 
Drawing also on the risk literature, trust is linked to fair behaviour by the proponents of the controversial activity (water reuse in this case) as well as to the provision of unbiased information on risks and benefits in the form of consultations with the community and all other stakeholders to enhance credibility (Price et al., 2015). One particularly important component of credibility and trust is professional competence. The public will be more likely to accept a water reuse scheme if it is perceived as being planned and managed by competent professionals and organizations (Ross et al., 2014). However, the public does not simply expect technical competence but competence tailored to specific contexts and problems. This brings in the issue of legitimacy as another important component of acceptance. In a review of some twenty water reuse projects in California, Harris-Lovett et al. (2015) found that projects that relied on technological competence alone (in the form of robust water treatment systems) were more likely to fail in terms of acceptance than projects in which competence embraced not only the technical dimension, but also the development of new standards and procedures regarding the management of these water reuse schemes. In sum, the provision of information on recycled water is likely to enhance acceptability versus no information at all (Fielding and Roiko, 2014), but the reception of information may also depend on preexisting attitudes. For example, De Koster and Achterberg (2015) found that new information on recycled water had only a certain impact upon people holding an already favourable view on these flows. Related to the arguments made above, risk communication is often placed at the centre of successful strategies to achieve public approval of water reuse schemes. Any risk communication process must be aware of the characteristics of the stakeholders and their expectations (Baggett et al., 2006). Procedurally, it is advisable that risk communication programmes begin before the specific project is designed and continue during all the phases of the project, especially during the operational phase (Attwater and Derry, 2005; Khan and Gerrard, 2006). Some researchers have emphasized the relevance of language in risk communication procedures. Thus the term 'recycled water' appears to induce more acceptance among urban consumers and farmers than the term 'treated wastewater', even when the two refer to the same effluent (Menegaki et al., 2009).

According to Hartley (2006) and in order to maintain public trust in any project, five broadly defined areas need to be considered: building and maintaining public confidence in water professionals and organizations; making information available to all parties involved; maintaining individual and organizational commitments; promoting dialog between parties; ensuring a fair and sound decision-making process and outcome, and building and maintaining overall trust. In this respect, strategies that consider the community context and promote education and participation are said to be critical for success (Russell et al., 2008). Here we can see another of the tenets of modern risk communication; namely, the fact that stakeholder engagement requires a careful consideration of stakeholder knowledge, aspirations and worldviews. This is best reflected in the concepts of 'co-learning' and 'social learning' (Moglia et 
Figure 3. Public acceptance of water reuse and degree of human contact

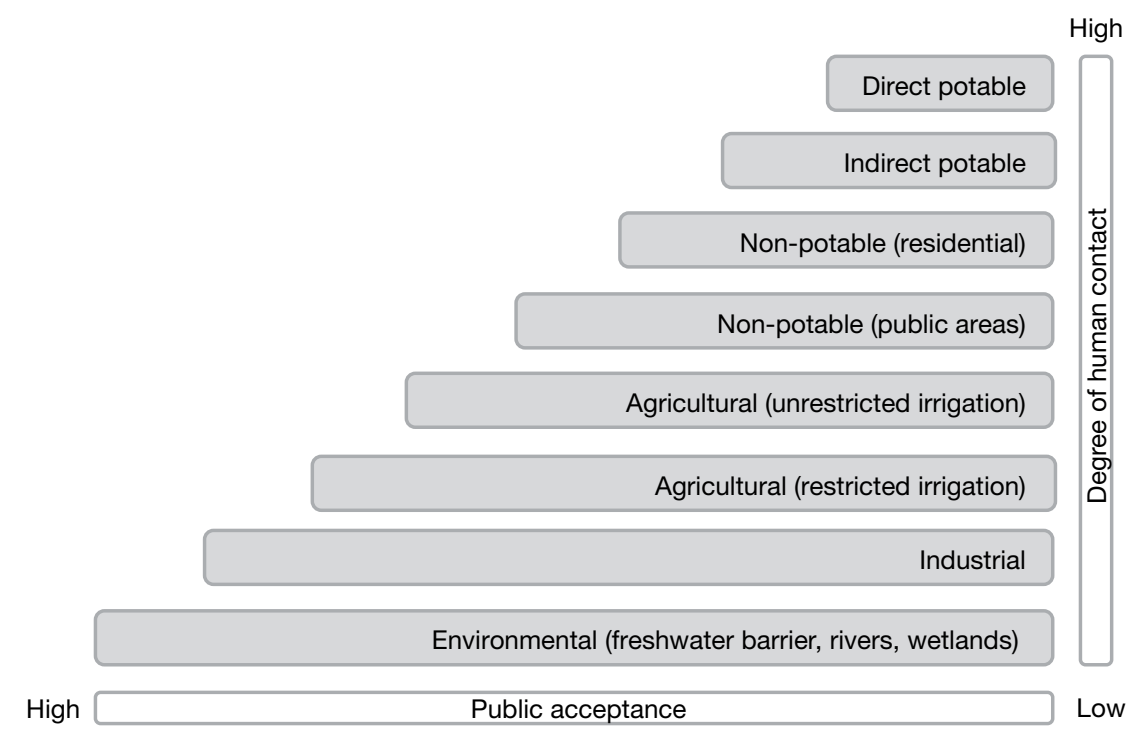

Source: The authors based on Stijn et al. (2015).

al., 2011), which may work better in accommodating the emotions and value judgements likely to arise in controversial projects. These factors should not be seen as irrational or irrelevant for scientific decision making but as elements that may broaden its basis (Morgan and Grant-Smith, 2015). In sum, the consideration of technical and social elements is likely to foster trust in, and acceptance of, water reuse (Marks and Zadoroznyj, 2005).

From the many studies devoted to examining people's response to and acceptance of water reuse, several findings appear consistently time and again (Kellis et al., 2013). Most importantly, extreme responses in the sense of total approval or rejection of recycled or reclaimed water are rare and acceptance is often contingent upon certain conditions, most notably the degree to which treated wastewater enters in direct contact with the human body (Mankad and Tapsuwan, 2011) (see also fig. 3). Several country or regional surveys support this assertion. A study in Israel, for example, considered 21 reuse options classified into three levels of contact. High-contact uses such as groundwater recharge for drinking purposes or food processing received little support; medium-contact uses such as garden irrigation or WC flushing received medium support; and some low-contact uses (for example, orchard irrigation) received less support than expected (Friedler et al., 2006). The latter result underline the special role of agricultural water reuse; one of the preferred options around the world that supplies as much as 50 percent of the water required for irrigation in countries such as Israel (Fluence 
News Team, 2017). The use of wastewater for agricultural irrigation is frequent in many areas of the world (Pedrero et al., 2010), especially in urban and periurban fringes, where wastewater is easily available at usually no cost. And yet, the use of recycled water for irrigating vegetable orchards raises concerns regarding, for instance, quality, food safety, consumer perceptions and reactions or uncertainties about the price of reclaimed water (Hamilton et al., 2005). Hurlimann and McKay (2006) examined how users may also feel appealed by certain aesthetic attributes of recycled water such as colour and odour. For certain uses (i.e. washing clothes) 'no colour' and 'no odour' would be critical, while for toilet flushing or garden watering they would be less relevant.

The extensive survey (nine countries) carried out by Hurlimann and Dolnicar (2016) confirms that alternative sources of water (desalinated water, recycled water and rainwater) have a higher acceptance when non-contact uses are involved. Therefore, adding new end uses for recycled water especially those involving direct or indirect contact with the human body (laundry, filling swimming pools) will remain a challenge (Chen et al., 2014). Non-potable reuse can contribute to enhancing the water supply portfolios although this is said to depend on the willingness of stakeholders to participate and negotiate new risk management practices and targets (Goodwin et al., 2017).

Research on perception and acceptance has also focused on the possibilities of potable water reuse. As indicated in Table 1, it is important to differentiate between direct and indirect potable water reuse. As expected, the latter, involving some kind of intermediate step between the recycled effluent and its final destination in drinking water purification plants, is much more preferred than the former, especially if public engagement is assured (Adams, 2014; Aitken et al., 2014). Still, there are a number of critical risks to the long-term viability of residential water reuse schemes. West et al. (2016) highlighted unanticipated economic costs and legal arrangements; regulations to be met in the approval process; and customer concerns, especially regarding health risks, no matter how low the actual impacts. Given the amount and complexity of information and actions to be taken, some authors (Dolnicar and Hurlimann, 2009) raise the poignant question of whether public consultation is needed to approve and generalize the use of alternative water resources.

\section{Conclusion: Towards a research agenda on water reuse based on social, territorial and environmental factors}

In this review, we have been primarily interested in the research on water reuse and very especially on the public perception and acceptance of this alternative water flow which, according to many and varied sources, will become a basic component of future water supply portfolios. A first point of interest is the expanding gap between wastewater treatment technology on the one hand, and the perceptions, concerns, attitudes and behaviours of the public on the other. Wastewater technology has progressed to the point that the quality of the effluent in the most advanced facilities is high enough to enter water purifica- 
tion plants ready to become drinking water. In other words, water quality can be produced on demand (Iglesias, 2016). However, the increasing analytical power to identify potentially dangerous substances in water at extremely tiny concentrations has 'discovered' new families of pollutants whose health impacts are still largely unknown although they are suspected to be hazardous. The effective removal of these substances needing very sophisticated and expensive additional treatments would probably translate into increasing costs to consumers who, on the other hand, may not feel comfortable in reusing the resulting effluents. The tension between the technical and the social will continue to require more research with several promising avenues, especially those attempting to break the strict distinction between the two views and pursue instead more relational approaches (Bell and Aitken, 2008).

Despite the vast research on water reuse in the social sciences, some potentially relevant aspects appear to have attracted little attention by researchers. First, concerns about social reactions to water reuse tend to include the 'public' as the main contender, but little is said about the reactions of other stakeholders, for instance health professionals. The latter have shown extraordinary awareness about the potential health problems associated with water reuse and have therefore been highly vigilant of water reuse schemes. In this sense, the consolidation of water reuse as a relevant component of the water supply matrix may require better coordination between agencies and government policies (Stenekes et al., 2006). Second, psychological and demographic profiles and characteristics abound in the identification of acceptance or refusal of water reuse schemes, but there appears to be less work on the role of social and territorial variables in terms of gender, class, ethnicity or income. In this sense, water reuse projects, like any other activity with an important risk potential, could also be approached from environmental justice perspectives. Third, and related to the previous point, there is still little literature on the political ecology of water reuse and how these new flows are interwoven with the rest of water flows circulating in urban water cycles. An interesting angle is who controls water reuse and whether water reuse can be considered a new 'accumulation frontier' for private companies. Fourth, water reuse also raises issues of scale and centralization of schemes. According to Meehan et al. (2013), successful reuse schemes projects are characterized by large-scale, centralized facilities under technoscientific control, the main objective of which is to increase water supply to feed urban expansion. In this respect, there is little explicit discussion on the relative merits and pitfalls of large, centralized schemes such as the conventional wastewater treatment plants and the smaller decentralized schemes such as the greywater treatment units installed in residential buildings. Here, too, issues of power and control on these flows can be raised. Fifth, the relationship between social requirements for the reduction of risk and the costs of such a reduction are also interesting to examine. Indeed, they are a point of concern for water companies and also an area of experimentation in social engineering in that these companies may seek novel ways to convince the public to be less risk averse or otherwise be prepared to face what would likely 
be very high economic costs. Sixth, it would be very interesting to examine the potential role that water reuse may play in future water supply portfolios related to urban and regional growth (Browning-Aiken et al., 2011). Another particular area of interest would be the role of water reuse in planning strategies to improve water security and reliability of large tourist destinations prone to episodes of water stress (Rico et al., 2013). Seventh, and with the Australian 'Millennium Drought' in mind, it would be very convenient to know more about the role that extreme events exert on fostering the adoption of new resources even when, as in water reuse, these may be controversial (Radcliffe, 2015). Likewise, climate change scenarios regarding water supplies may situate reclaimed water in a strategic position (IPCC, 2014). Eighth, economic and financial issues also require more attention with the challenging objective of designing tariff structures for recycled water that reflect costs but also fairness (Molinos-Senante et al., 2013). A further interesting point here are the tradeoffs between cost and risk, especially regarding potentially harmful substances found at extremely low concentrations. Ninth, the potentially negative effects of direct reuse on water flows and water ecosystems must also be borne in mind as these effluents are not released into the natural environment (rivers and public channels). This aspect acquires special importance in certain areas of the Mediterranean, where treated wastewater that returns to the rivers constitutes a significant portion of water flows. Finally, historical studies and the consideration of historical background would probably help to contextualize the analysis of certain cases.

\section{Bibliographical references}

ADAMS, Ellis Adjei (2014). "Behavioral Attitudes towards Water Conservation and Reuse among the United States Public". Resources and Environment, 4 (3), 162-167. $<$ https://doi.org/10.5923/j.re.20140403.04>

AitKen, Victoria; Bell, Sarah; Hills, Sian and Rees, Lucy (2014). "Public acceptability of indirect potable water reuse in the south-east of England". Water Science \& Technology Water Supply, 14 (5), 875-885.

Almeida, Maria do Ceu; VieIra, Paula and Smeets, Peter (2014). "Extending the water safety plan concept to the urban water cycle". Water Policy, 16, 298-322. $<$ https://doi.org/10.2166/wp.2013.137>

Anderson, Jessica; Adin, Avner; CrooK, James; DAvis, Clodoveu; HultQuist, R. H.; Jimenez-Cisneros, Blanca; Kennedy, Wendy; SheikH, Bahman and Van Der Merwe, Belinda (2001). "Climbing the ladder: a step by step approach to international guidelines for water recycling”. Water Science and Technology, 43 (10), 1-8.

ARAHUETES, Ana (2017). Los recursos no convencionales en el metabolismo hidrico del litoral de la provincia de Alicante. Doctoral thesis. Alicante: Universidad de Alicante.

ATTWATER, Roger and DERRY, Chris (2005). "Engaging communities of practice for risk communication in the Hawkesbury Water Recycling Scheme". Action Research, 3 (2), 193-209.

<https://doi.org/10.1177/1476750305052144> 
Baggett, Steve; Jeffrey, Paul and JefFerson, Bruce (2006). "Risk perception in participatory planning for water reuse". Desalination, 187, 149-158. <https://doi.org/10.1016/j.desal.2005.04.075>

BELL, Sarah and AITKEN, Victoria (2008). "The socio-technology of indirect potable water reuse”. Water Science \& Technology: Water Supply-WSTWS, 8 (4), 441-448.

Browning-Aiken, Anne; Ormerod, Kerry Jean and SCOTt, Christopher A. (2011). "Testing the Climate for Non-Potable Water Reuse: Opportunities and Challenges in Water-Scarce Urban Growth Corridors". Journal of Environmental Policy \& Planning, 13 (3), 253-275.

<https://doi.org/10.1080/1523908X.2011.594597>

Chen, Zhou; NgO, Huu Hao; GuO, Wenshan; Lim, Richard P.; Wang, Xiaochang C.; O’Halloran, Kelly; Listowski, Andrzej; Corby, Nigel and Miechel, Clayton (2014). "A comprehensive framework for the assessment of new end uses in recycled water schemes". Science of the Total Environment, 470-471, 44-52. <http://dx.doi.org/10.1016/j.scitotenv.2013.09.061>

De Koster, Willem and Achterberg, Peter (2015). "Comment on "Providing information promotes greater public suport for potable recycled water". Water Research, $84,372-374$. <http://dx.doi.org/10.1016/j.watres.2015.05.067>

Dolnicar, Sara and Hurlimann, Anne (2009). "Drinking water from alternative water sources: differences in beliefs, social norms and factors of perceived behavioural control across eight Australian locations". Water Science \& Technology, 60 (6), 1433-1444.

Dominguez-Chicas, Angelina and Scrimshaw, Mark D. (2010). "Hazard and risk assessment for indirect potable reuse schemes: An approach for use in developing Water Safety Plans". Water Research, 44, 6115-6123. <https://doi.org/10.1016/j.watres.2010.07.007>

DuONG, Kimberly and SAPHORES, Jean-Daniel M. (2015). "Obstacles to wastewater reuse: an overview". WIREs Water, 2, 199-214. <https://doi.org/10.1002/wat2.1074>

EUROPEAN UNION (2017). Water Reuse - Background and policy context. <http:// ec.europa.eu/environment/water/reuse.htm> [accessed 10 February 2018].

Fawell, John; Le Corre, Kristell and JefFrey, Paul (2016). "Common or independent? The debate over regulations and standards for water reuse in Europe". International Journal of Water Resources Development, 32 (4), 559-572. <https://doi.org/10.1080/07900627.2016.1138399>

FIELDinG, Kelly S. and RoikO, Anne H. (2014). "Providing information promotes greater public support for potable recycled water". Water Research, 61, 86-96. <http://dx.doi.org/10.1016/j.watres.2014.05.002>

Fluence News TeAm (2017). Israel Leads World in Water Recycling. <https:/www.fluencecorp.com/israel-leads-world-in-water-recycling/> [accessed: 12 February 2018].

FRIEDLER, Eran; LAHAV, Ori; JIZHAK, Hagar and LAHAV, Tali (2006). "Study of urban population attitudes towards various wastewater reuse options: Israel as a case study". Journal of Environmental Management, 81, 360-370. <https://doi.org/10.1016/j.jenvman.2005.11.013>

Fundación Nueva Cultura del Agua (2018). Propuestas de la Fundación Nueva Cultura del Agua para una Política Sostenible del Agua. <https://fnca.eu/images/ documentos/DOCUMENTOS/20180116_Propuestas_politica_sostenible_agua_ FNCA.pdf> [accessed 3 March 2018]. 
Goodwin, Daniel; Raffin, Marie; Jeffrey, Paul and Smith, Heather (2017). "Collaboration on risk management: The governance of a non-potable water reuse scheme in London". Journal of Hydrology, in press. <http://dx.doi.org/10.1016/j.jhydrol.2017.07.020>

Hall, Jim and BorgOMeO, Edoardo (2013). "Risk-based principles for defining and managing water security”. Philosophical Transactions of the Royal Society A, 371. <http://dx.doi.org/10.1098/rsta.2012.0407>

Hamilton, Andrew John; Boland, Anne-Maree; Stevens, Daryl; Kelly, Jim; RadCliffe, John; Ziehrl, Angelika; Dillon, Peter and Paulin, Bob (2005). "Position of the Australian horticultural industry with respect to the use of reclaimed water". Agricultural Water Management, 71, 181-209. <https://doi.org/10.1016/j.agwat.2004.11.001>

Harris-LovetT, Sasha R.; BinZ, Christian; SedlaK, David; Kiparsky, Michael L. and TrufFER, Bernhard (2015). "Beyond User Acceptance: A Legitimacy Framework for Potable Water Reuse in California”. Environmental Science and Technology, 49, 7552-7561. <https://doi.org/10.1021/acs.est.5b00504>

Hartley, Troy W. (2006). "Public perception and participation in water reuse". Desalination, 187, 115-126. <https://doi.org/10.1016/j.desal.2005.04.072>

Hurlimann, Anna (2007). "Is recycled water use risky? An Urban Australian community's perspective”. Environmentalist, 27, 83-94. <https://doi.org/10.1007/s10669-007-9019-6>

Hurlimann Anna and Dolnicar, Sara (2010). "When public opposition defeats alternative water projects - The case of Toowoomba Australia". Water Research, 44, 287-297. <https://doi.org/10.1016/j.watres.2009.09.020>

- (2016). "Public acceptance and perceptions of alternative water sources: a comparative study in nine locations". International Journal of Water Resources Development, 32 (4), 650-673.

Hurlimann, Anna and McKay, Jennifer M. (2006). "What attributes of recycled water make it fit for residential purposes? The Mawson Lakes experience". Desalination, 187, 167-177. <https://doi.org/10.1016/j.desal.2005.04.077>

IGLESIAS, Raquel (2016). La reutilización de efluentes depurados en España: retrospectiva, desarrollo del marco normativo, estudio de las tecnologías de regeneración frente a los biorreactores de membrana y sus costes en función del uso. Doctoral thesis. Madrid: Universidad Politécnica de Madrid.

IPCC, Intergovernmental Panel on Climate Change (2014). "Climate Change 2013 and climate change 2014 (3 vols.)”. <http://www.ipcc.ch/> [accessed 21 July 2017].

JonAS, Margot; Rossi, Luca; BARry, David A. and Holliger, Christof (2015). "A review of the fate of micropollutants in wastewater treatment plants". WIREs Water, 2, 457-487. <https://doi.org/10.1002/wat2.1090>

Kellis, Manolis; Kalavrouziotis; Ioannis K. and Gikas, Petros (2013). "Review of Wastewater Reuse in Mediterranean Countries, focusing on regulations and policies for municipal and industrial applications". Global NEST Journal, 15 (3), 333-350.

KHAN, Stuart J. and Gerrard, Lis E. (2006). Stakeholder communications for successful water reuse operations. Desalination, 187, 191-202. 
Kot, Megan; Castleden, Heather and Gagnon, Graham A. (2015). "The human dimension of water safety plans: a critical review of literature and information gaps". Environmental Review, 23, 24-29. <https://doi.org/10.1139/er-2014-0030>

LA VANGUARdia (2018) El presidente de Agbar ve "inaplazable" la apuesta por la reutilización del agua. <http://www.lavanguardia.com/local/barcelona/20180123/44243010813/agbar-angel-simon-reutilizacion-agua-sequia.html> [accessed: 23 January 2018].

LATOUR, Bruno (2005). Reassembling the social: an introduction to actor-network-theory. Oxford: Clarendon Press.

LEVINE, Audrey D. and Asano, Takashi (2004). "Recovering sustainable water from wastewater". Environmental Science and Technology, June 1, 201-208.

MANKAD, Aditi and TAPSUWAN, Sorada (2011). "Review of socio-economic drivers of community acceptance and adoption of decentralised water systems". Journal of Environmental Management, 92, 380-391. <https://doi.org/10.1016/j.jenvman.2010.10.037>

MARKS, June S. (2006). "Taking the public seriously: the case of potable and non potable reuse". Desalination, 187, 137-147. <https://doi.org/10.1016/j.desal.2005.04.074>

MARKS, June S. and ZADOROZNYJ, Maria (2005). "Managing Sustainable Urban Water Reuse: Structural Context and Cultures of Trust". Society and Natural Resources, 18 (6), 557-572. <https://doi.org/10.1080/08941920590947995>

MARKS, June; MARTIN, Bill and ZADOROZNYJ, Maria (2008). "How Australians order acceptance of recycled Water. National baseline data". Journal of Sociology, 44 (1), 83-99. <https://doi.org/10.1177/1440783307085844>

Meehan, Karen; Ormerod, Kelly Jean and Moore, Sarah A. (2013). "Remaking waste as water: The governance of recycled effluent for potable water supply". Water Alternatives, 6 (1), 67-85.

Melgarejo, Joaquín and LÓPEZ, Maria Inmaculada (2016). "Depuración y reutilización de aguas en España”. Agua y Territorio, 8, 22-35. <https://doi.org/10.17561/at.v0i8.3293>

Menegaki, Angeliki N.; Mellon, Robert C.; Vrentzou, Anna; Koumakis, George and Tsagarakis, Konstantinos P. (2009). "What's in a name: Framing treated wastewater as recycled water increases willingness to use and willingness to pay". Journal of Economic Psychology, 30, 285-292. <https://doi.org/10.1016/j.joep.2008.08.007>

Moglia, Magnus; Alexander, K. S. and Sharma, Ashkok (2011). "Discussion of the Enabling Environments for Decentralised Water Systems". Water Science and Technology, 63 (10), 2331-2339. <https://doi.org/10.2166/wst.2011.443>

Molinos-Senante, Maria; Hernandez-Sancho, Francesc and Sala-Garrido, Ramon (2013). "Tariffs and Cost Recovery in Water Reuse". Water Resources Management, 27, 1797-1808. <https://doi.org/10.1007/s11269-012-0111-4>

Montes-Grajales, Diana; Fennix-Agudelo, Mary and Miranda-Castro, Wendy (2017). "Occurrence of personal care products as emerging chemicals of concern in water resources: A review". Science of the Total Environment, 595, 601-614. <http://dx.doi.org/10.1016/j.scitotenv.2017.03.286> 
Morgan, Edward Alexander and Grant-Smith, Deanna Chantal Cristina (2015). "Tales of science and defiance: the case for co-learning and collaboration in bridging the science/emotion divide in water recycling debates". Journal of Environmental Planning and Management, 58 (10), 1770-1788.

<https://doi.org/10.1080/09640568.2014.954691>

Mujeriego, Rafael (2015). "Reutilización Potable Directa en Namibia: Pasado y futuro". <http://www.iagua.es/blogs/rafael-mujeriego/reutilizacion-potable-directa-namibia-pasado-y-futuro> [accessed 22 June 2017].

Ormerod, Kerri Jean and ScOTT, Christopher A. (2012). "Drinking Wastewater: Public Trust in Potable Reuse”. Science, Technology, \& Human Values, 38 (3), 351-373. <https://doi.org/10.1177/0162243912444736>

Pedrero, Francisco; Kalavrouziotis, Ioannis; Alarcón, Juan José; Koukoulakis, Prodromos and ASANO, Takashi (2010). "Use of treated municipal wastewater in irrigated agriculture-Review of some practices in Spain and Greece”. Agricultural Water Management, 97, 1233-1241. $<$ https://doi.org/10.1016/j.agwat.2010.03.003>

Perez, Sandra; Kock, Marianne; Tong, Lei; Ginebreda, Antoni; Lopez-Serna, Rebeca; Postigo, Cristina; Brix, Rikke; LoPez De AldA, Miren; Petrovic, Mira; WANG, Yanxin and BARCELÓ, Damià (2010). "Wastewater Reuse in the Mediterranean Area of Catalonia, Spain: Case Study of Reuse of Tertiary Effluent from a Wastewater Treatment Plant at el Prat de Llobregat (Barcelona)". In: D. BARCELO and M. PETROVIC (eds.). Waste Water Treatment and Reuse in the Mediterranean Region. The Handbook of Environmental Chemistry. Heidelberg: Springer, vol. 14, 249-294. <https://doi.org/10.1007/698_2010_88>

PO, Murni; NANCARROW, Blair E. and KAERCHER, Juliane E. (2003). Literature review of factors influencing public perceptions of water reuse. Melbourne: CSIRO Land and Water.

Price, Jennifer; Fielding, Kelly and Leviston, Zoe (2012). "Supporters and Opponents of Potable Recycled Water: Culture and Cognition in the Toowoomba Referendum". Society and Natural Resources, 25 (10), 980-995. <https://doi.org/10.1080/08941920.2012.656185>

Price, Jennifer; Fielding, Kelly, J.; Gardner, John; Leviston, Zoe and Green, M. (2015). "Developing effective messages about potable recycled water: The importance of message structure and content". Water Resources Research, 51, 2174-2187. <https://doi.org/10.1002/2014WR016514>

RADCLIFFE, John C. (2015). "Water recycling in Australia - during and after the drought". Environmental Science: Water Resources Technology, 1, 554. <https://doi.org/10.1039/c5ew00048c>

Rico, Antonio Manuel; Sauri, David; Olcina, Jorge and Vera, José Fernando (2013). "Beyond megaprojects? Water alternatives for mass tourism in coastal Mediterranean Spain”. Water Resources Management, 27, 553-565.

Ross, Victoria L.; FIELDING Kelly S. and Louis, Winnifred R. (2014). "Social trust, risk perceptions and public acceptance of recycled water: Testing a social-psychological model". Journal of Environmental Management, 137, 61-68. <http://dx.doi.org/10.1016/j.jenvman.2014.01.039>

Rozin, Paul; Haddad, Brent; Nemeroff, Carol and Slovic, Paul (2015). "Psychological aspects of the rejection of recycled water: Contamination, purification and disgust". Judgment and Decision Making, 10 (1), 1-14. 
Russell, Steward and Hampton, Greg (2006). "Challenges in understanding public responses and providing effective public consultation on water reuse". Desalination, 187, 215-227. $<$ https://doi.org/10.1016/j.desal.2005.04.081>

Russell, Stewart; LuX, Colleen and HAMPTON, Greg (2008). “Beyond 'Information': Integrating Consultation and Education for Water Recycling Initiatives". Society and Natural Resources, 22 (1), 56-65. <https://doi.org/10.1080/08941920801910666>

Soon, Tan Yong; Jean, Lee Tung and Tan, Karen (2008). Clean, Green and Blue: Singapore's Journey Towards Environmental and Water Sustainability. Singapore: Institute of Southeast Asian Studies.

Stenekes, Nyree; Colebatch, Hal K.; Waite, T. David and Ashbolt, Nick J. (2006). "Risk and Governance in Water Recycling. Public Acceptance Revisited". Science, Technology, \& Human Values, 31 (2), 107-134. <https://doi.org/10.1177/0162243905283636>

STIJN, Brouwer; MAAS, Timo; SMiTH, Heather and Frijns, Joos (2015). Trust in Water Reuse: Review report on international experiences in public involvement and stakeholder collaboration. Demoware Project D5.2 <http://demoware.eu/en/results/ deliverables/deliverable-d5-2-trust-in-reuse.pdf> [accessed 23 November 2017].

Van Vuuren, Kitty (2009). "Press Bias and Local Power in the Toowoomba water referendum”. Communication, Politics \& Culture, 42 (1), 55-73.

West, Camilla; Kenway, Steven; Hassall Maureen and Yuan Zhiguo (2016). "Why do residential recycled water schemes fail? A comprehensive review of risk factors and impact on objectives". Water Research, 102, 271-281.

<http://dx.doi.org/10.1016/j.watres.2016.06.044>

Wester, Julia; TimPano, Kiara R.; ÇeK, Demet; Lieberman, Debra; Fieldstone Shaina C. and BroAD, Kenneth (2015). "Psychological and social factors associated with wastewater reuse emotional discomfort". Journal of Environmental Psychology, 42, 16-23. <http://dx.doi.org/10.1016/j.jenvp.2015.01.003>

Wester, Julia; Timpano, Kiara R.; ÇeK, Demet and Broad, Kenneth (2016). "The psychology of recycled water: Factors predicting disgust and willingness to use". Water Resources Research, 52, 3212-3226. <https://doi.org/10.1002/2015WR018340>

WWAP (United Nations World Water Assessment Programme) (2017). The United Nations World Water Development Report 2017. Wastewater: The Untapped Resource. Paris: UNESCO.

YanG, Yi; OK, Yong Sik; Kim, Ki-Hyun; KwOn, Eilhann E. and Tsang, Yiu Fai (2017). "Occurrences and removal of pharmaceuticals and personal care products (PPCPs) in drinking water and water/sewage treatment plants: A review". Science of the Total Environment, 596-597, 303-320.

<http://dx.doi.org/10.1016/j.scitotenv.2017.04.102> 